Buletin JSJ, 2 (1), 2020, 37-47

Available online di: http://ejournal-balitbang.kkp.go.id/index.php/JSJ/index

\title{
KAJIAN TEKNIS PEMBESARAN UDANG VANAME (Litopenaeus vannamei) DI PT SURI TANI PEMUKA,BANYUWANGI - JAWA TIMUR
}

\section{TECHNICAL STUDY OF VANAME SHIRMP CULTIVATION (LitopenaeuS vannamei) IN PT. SURI TANI PEMUKA, BANYUWANGI - EAST JAVA}

\author{
Deby Tiara Sandi'), Sinung Rahardjo'), Erni Marlina ${ }^{2)}$ \\ Politeknik Ahli Usaha Perikanan \\ JI. AUP No.1 Pasar Minggu - Jakarta Selatan \\ Email: debytiara52@gmail.com
}

\begin{abstract}
ABSTRAK
Udang vaname (L. vannameI) adalah komoditas yang berkembang pesat dengan keunggulan pertumbuhannya cepat, dan mempunyai harga pasar yang cukup tinggi dan secara ekonomi udang vaname memberikan kontribusi terhadap nilai ekspor hasil produksi perikanan di Indonesia yaitu sebesar $33,1 \%$. Upaya yang dipenuhi untuk kebutuhan konsumsi yang berkualitas maka dibutuhkan pengelolaan teknis dan sumberdaya yang mencukupi serta diperlukannya teknologi yang tepat. Seiring berkembangnya teknologi, udang vaname ( $L$. vannamei) telah dikembangkan dengan sistem intensif dan supra intensif. Salah satu potensi tambak di Indonesia adalah PT Suri Tani Pemuka, yang merupakan salah satu perusahaan yang aktif dalam memproduksi dan pengembangan budidaya udang yang telah menerapkan teknologi intensif. Pengamatan ini dilaksanakan di PT Suri Tani Pemuka, Banyuwangi pada tanggal 2 September sampai dengan 30 Oktober 2019. Tujuan pengamatan adalah mengevaluasi aspek teknis, performansi kinerja budidaya udang vaname, aspek finansial dan identikikasi masalah. Metode observasi dan wawancara digunakan untuk mengumpulkan data primer maupun sekunder. Aspek teknis dan performansi kinerja budidaya udang vaname di PT STP belum mencapai standar yang berlaku yang diterapkan oleh perusahaan yaitu rata-rata produkttivitas $82 \%$, SR $78 \%$, FCR $58 \%$, ABW 0\%, dan ADG 66\%
\end{abstract}

Kata kunci : Aspek Teknis, Kinerja Budidaya, Identifikasi Masalah

\begin{abstract}
ABSTRACK
Vaname shrimp (L. vannamei) is a fast growing commodity, and has a fairly high and economical market price of vaname shrimp contributing to the export value of agricultural production in Indonesia by $33.1 \%$. The effort needed for consumption needs is needed, so technical and sufficient resources are needed and the right technology is needed. As technology develops, vaname shrimp (L. vannamei) has been developed with intensive and supra intensive systems. One of the potential ponds in Indonesia is PT Suri TaniPemuka, which is one of the companies that is active in producing and developing shrimp farming that has implemented intensive technology. This observation was carried out at PT Suri TaniPemuka, Banyuwangi on 2 September to 30 October 2019. The objective of the observation was the aspect of technical planning, the performance of the development of vaname shrimp culture, financial aspects and issues related to the indication. Observation and interview methods are used to collect primary and secondary data. The technical and performance aspects of the development of vaname shrimp culture at PT STP have not yet reached the standards applied by the company, which are products on average $82 \%$, SR $78 \%$, FCR $58 \%$, ABW 0\%, and ADG 66\%.
\end{abstract}

Keywords: Technical Aspects, Cultivation Performance, Problem Identification 
Buletin JSJ, 2 (1), 2020, 37-47

Available online di: http://ejournal-balitbang.kkp.go.id/index.php/JSJ/index

\section{PENDAHULUAN}

Udang vaname (Litopenaeus vannamel) merupakan salah satu komoditas perikanan laut yang memiliki nilai ekonomis tinggi baik di pasar domestik maupun global, dimana $77 \%$ diantaranya diproduksi oleh negara-negara Asia termasuk Indonesia (Dahlan dkk., 2017). Udang vaname Litopenaeus vannamei merupakan salah satu komoditas perikanan yang sedang dikembangkan dalam usaha budidaya di tambak (Budiardi dkk., 2005)

karena produktivitasnya tinggi serta meningkatnya permintaan pasar akan komoditas ini di luar negeri (Dede dkk., 2014). Berdasarkan data Statistik Ekspor Perikanan Indonesia, nilai ekspor udang Indonesia ke mancanegara mengalami peningkatan dari tahun ke tahun, pada tahun 2011 ekspor udang mencapai 4,158 ton dan meningkat pada tahun 2012 menjadi 6,582 ton dengan peningkatan per tahun sebesar 58\% (Badan Pusat Statistik, 2012) Hal ini berarti peluang untuk mengembangkan udang vaname semakin tinggi.

\section{METODE PENELITIAN}

\section{Waktu dan Tempat}

Penelitian ini dilaksanakan di PT. Suri Tani Pemuka, Kabupaten Banyuwangi, Jawa Timur pada tanggal 02 September hingga 30 Oktober 2019.

\section{Metode Pengumpulan Data}

Metode pengumpulan data yang diterapkan dalam penelitian adalah metode observasi, wawancara, studi literatur, dan berpartisipasi dalam semua kegiatan budidaya udang vaname secara langsung di lapangan. Variabel performansi kinerja budidaya yang diamati meliputi produktivitas, survival rate (SR), Food Convertion Rate (FCR), Average Body Weight (ABW), Average Daily Growth (ADG) dan Kualitas Air. Metode pemeliharaan atau teknis produksi selama pengamatan yang dilakukan yaitu disajikan pada Tabel 1.

Tabel 1. Deskripsi teknis produksi yang dilakukan diberi terjemahan

\begin{tabular}{|c|c|c|}
\hline No & Tahapan Produksi & Deskripsi \\
\hline \multirow[t]{3}{*}{1.} & Persiapan Wadah & $\begin{array}{l}\text { a. Pengeringan wadah yang dilakukan dengan } \\
\text { membiarkan wadah yang sudah dibersihkan terkena } \\
\text { sinar matahari sampai kering, tanpa melakukan } \\
\text { perlakuan apapun. Lama waktu pengeringan yang } \\
\text { dibutuhkan adalah 5-7 hari. }\end{array}$ \\
\hline & & $\begin{array}{l}\text { b. Pembersihan tambak meliputi pengerokan lumut } \\
\text { yang terdapat di dinding tambak dan kincir, } \\
\text { pembersihan kotoran dan penyemprotan tambak } \\
\text { dengan menggunakan air laut dan sterilisasi dengan } \\
\text { penyiraman dinding dan dasar tambak } \\
\text { menggunakan Kaporit } 60 \% \text { dengan dosis } 5 \mathrm{mg} / \mathrm{l} \\
\text { yang dilarutkan dengan air tawar dengan cara } \\
\text { menyiram keseluruh permukaan tambak dan } \\
\text { didiamkan selama } 1-2 \text { hari }\end{array}$ \\
\hline & & $\begin{array}{l}\text { c. Perbaikan sarana dan prasarana pemasangan } \\
\text { biosecurity, penutupan pintu air, pemasangan skala } \\
\text { tinggi air, perbaikan bantalan kincir, pemasangan }\end{array}$ \\
\hline
\end{tabular}


Buletin JSJ, 2 (1), 2020, 37-47

Available online di: http://ejournal-balitbang.kkp.go.id/index.php/JSJ/index

\begin{tabular}{|c|c|c|c|}
\hline & & & $\begin{array}{l}\text { anco dan perbaikan jembatan anco serta } \\
\text { pengumpulan kembali alat-alat yang akan dilakukan } \\
\text { dalam kegiatan budidaya udang vaname. }\end{array}$ \\
\hline \multirow[t]{3}{*}{2.} & \multirow[t]{3}{*}{ Persiapan Media } & a. & $\begin{array}{l}\text { Sterilisasi air media dilakukan di tandon yaitu dengan } \\
\text { pengaplikasian kaporit berbahan aktif } 60 \% \text { dengan } \\
\text { dosis } 30 \mathrm{mg} / \mathrm{L} \text { dimana kincir } 24 \text { beroperasi hingga } \\
\text { kandungan chlorine sudah tidak ada, setelah itu air } \\
\text { laut dialirkan kedalam petak pemeliharaan hingga } \\
\text { ketinggian } 100 \mathrm{~cm} \text { dengan menggunakan pompa } \\
\text { submersible merek dagang ebara } 10 \text { inch. }\end{array}$ \\
\hline & & b. & $\begin{array}{l}\text { Desinfeksi air pada petak pemeliharaan yaitu dengan } \\
\text { tujuan untuk memastikan bahwa air terbebas dari } \\
\text { organisme yang tidak diinginkan. Pada hari pertama } \\
\text { dilakukan deisinfeksi dengan pengaplikasian } \\
\text { desinfektan copper sulfate (CuSO4) dosis } 3 \mathrm{mg} / \mathrm{L} \text {. } \\
\text { Keesokan harinya pengaplikasian delstar } 2 \mathrm{ml} / \mathrm{m}^{3} \text {. } \\
\text { Bahan desinfektan ini dimaksudkan untuk } \\
\text { mematikan moluska, kepiting, udang liar atau biota } \\
\text { air pengganggu lainya yang terdapat dipetakan. } \\
\text { Setelah } 24 \text { jam. }\end{array}$ \\
\hline & & c. & $\begin{array}{l}\text { Perlakuan untuk penumbuhan plankton yang } \\
\text { dilakukan adalah pengapuran, pemupukan dan } \\
\text { pemberian probiotik. Pengapuran menggunakan } \\
\text { kapur dolomit dan kaptan dengan dosis masing- } \\
\text { masing } 10 \mathrm{~g} / \mathrm{m}^{3} \text {. Pemupukan dilakukan dengan } \\
\text { menggunakan pupuk ZA. Pupuk ZA ditebar setiap } 4 \\
\text { hari sekali dengan dosis } 5 \mathrm{~g} / \mathrm{m}^{3} \text {.Pemberian Probiotik } \\
\text { yaitu merek dagang promix dimana probiotik } \\
\text { mengandung koloni bakteri Bacillus dan bakteri } \\
\text { Thiobacillus. Kultur fermentasi bakteri berlangsung } \\
\text { selama } 24 \text { jam dimana probiotik difermentasi dengan } \\
\text { penambahan nutrien dari produk yang sama dimana } \\
\text { nutrien probiotik mengandung unsur karbon untuk } \\
\text { pertumbuhan dan meningkatkan aktifitas bakteri } \\
\text { yang terdapat dalam probiotik. Adapun dosis } \\
\text { pemberian probiotik dan nutrien probiotik yaitu } \\
\text { masing-masing } 1,2 \mathrm{ml} / \mathrm{m}^{3} \text { dan dosis nutiren yaitu } 1,2 \\
\mathrm{~g} / \mathrm{m}^{3} \text {. }\end{array}$ \\
\hline \multirow[t]{2}{*}{3.} & \multirow[t]{2}{*}{ Penebaran benur } & a. & $\begin{array}{l}\text { Sebelum ditebar, benur dihitung dan diuji kembali. } \\
\text { Pengujian dilakukan dengan parameter yang sama } \\
\text { seperti proses seleksi. Benur yang tiba di hitung } \\
\text { menggunakan teknik sampling acak yaitu dengan } \\
\text { mengambil } 2 \text { kantong benur secara acak. }\end{array}$ \\
\hline & & & $\begin{array}{l}\text { Teknik penebaran benur yaitu dengan aklimatisasi } \\
\text { benur terlebih dahulu. Aklimatisasi dilakukan pada } \\
\text { suhu lingkungan yang rendah yaitu dilakukan pada } \\
\text { pukul } 05.30 \text { WIB. Dimana benur, dimasukkan ke } \\
\text { dalam petakan tambak yang pada bagian sudut } \\
\text { tambak diberi bambu sebagai alat penahan agar }\end{array}$ \\
\hline
\end{tabular}


Buletin JSJ, 2 (1), 2020, 37-47

Available online di: http://ejournal-balitbang.kkp.go.id/index.php/JSJ/index

\begin{tabular}{|c|c|c|}
\hline & & $\begin{array}{l}\text { kantong benur tidak menyebar ke seluruh petakan } \\
\text { tambak, lalu benur dibiarkan mengapung selama } 30 \\
\text { menit sampai terdapat embun di dalam kantong } \\
\text { dengan asumsi bahwa suhu dalam kantong telah } \\
\text { sama dengan suhu air tambak. Selanjutnya kantung } \\
\text { benur dibuka dan benur diapungkan dengan ember } \\
\text { yang disertai aerasi, bertujuan untuk mengurangi } \\
\text { tingkat stres pada benur. Setelah } 5 \text { menit, benur } \\
\text { perlahan ditebar ke petakan tambak. }\end{array}$ \\
\hline 4 & Pengelolaan Pakan & $\begin{array}{l}\text { Pakan buatan yang digunakan untuk produksi udang } \\
\text { vaname di PT. STP Unit Sobo merupakan pakan buatan } \\
\text { yang diproduksi oleh PT. Suri Tani Pemuka unit Pakan } \\
\text { udang dengan merek pakan yaitu PV dan SGH. Pada DOC } \\
1-12 \text { masih menggunakan pakan dengan bentuk powder, } \\
\text { DOC 13-20 sudah menggunakan pakan dengan bentuk } \\
\text { crumble, Setelah masuk DOC } 30 \text {-panen udang diberikan } \\
\text { pakan dengan bentuk pellet dengan menggunakan alat } \\
\text { pemberian pakan otomatis atau autofeeder. Adapun teknik } \\
\text { perhitungan pakan, awal tebar benur yaitu menggunakan } \\
\text { perhitungan pakan buta blind feed, pada DOC } 40 \text { setelah } \\
\text { dilakukannya panen, perhitungan pakan berdasarkan FR } \\
\text { terhadap abw udang. }\end{array}$ \\
\hline 5 & Monitoring Pertumbuhan & $\begin{array}{l}\text { Monitoring pertumbuhan dilakukan untuk melihat nafsu } \\
\text { makan udang, dan mengetahui kondisi kesehatan. } \\
\text { Sampling pertumbuhan dilakukan dengan mengambil } \\
\text { sampel udang dianco pada petak pemeliharaan, dan } \\
\text { dilakukan penimbangan dan penghitungan udang. }\end{array}$ \\
\hline 6 & Manajemen Air & $\begin{array}{l}\text { a. Kualitas air dengan pengukuran : } \\
\text { b. Suhu, salinitas, pH, DO, kecerahan, alkalinitas, TOM, } \\
\text { Nitrit, Amonia, } \\
\text { c. Kuantitas air dengan perlakuan : } \\
\text { d. Pergantian air dan penambahan air } \\
\text { e. Pengeolaan air } \\
\text { f. Aplikasi probiotik, Pengapuran, dan Penyiphonan. }\end{array}$ \\
\hline 7 & $\begin{array}{l}\text { Pengendalian hama } \\
\text { penyakit }\end{array}$ & $\begin{array}{l}\text { Secara umum perusahaan menjalankan kaidah-kaidah } \\
\text { 'Biosecurity' seperti : pagar kepiting, BSD (Bird Scaring } \\
\text { Device), serta penyediaan wadah cuci tanggan } \\
\text { menggunakan larutan PK pada setiap petakan tambak. }\end{array}$ \\
\hline 8 & Panen dan pasca panen & $\begin{array}{l}\text { Panen yang dilakukan dengan menggunakan } 2 \text { cara, yaitu } \\
\text { sistem panen parsial dan panen total. Panen parsial } \\
\text { dilakukan } 2 \text { hingga } 3 \text { kali tergantung dari hasil sampling. } \\
\text { Adapun cara melakukan panen parsial yaitu kincir } \\
\text { dimatikan pada daerah titik penjalaan, sebelum jala ditebar } \\
\text { ke petakan tambak. Panen total umumnya dilakukan pada } \\
\text { umur } 100 \text { dan tergantung kondisi udang pemeliharaan } \\
\text { Panen total dilakukan pada pagi hari hingga sore hari } \\
\text { menggunakan jala dan dibantu dengan jaring kantong yang } \\
\text { dipasang di pintu pengeluaran (outlet), kemudian pintu air }\end{array}$ \\
\hline
\end{tabular}


Buletin JSJ, 2 (1), 2020, 37-47

Available online di: http://ejournal-balitbang.kkp.go.id/index.php/JSJ/index

\begin{tabular}{|l|l|l|}
\hline & $\begin{array}{l}\text { dibuka dan udang akan keluar dengan sendirinya mengikuti } \\
\text { arus akan terperangkap di dalam jaring panen. }\end{array}$ \\
\hline
\end{tabular}

\section{Metode Pengolahan dan Anaisis data}

Indikator performansi kinerja budidaya yang digunakan sebagai acuan tingkat keberhasilan produksi meliputi Produktivitas, Survival rate (SR) efisiensi pakan/ Feed Convertion Ratio (FCR), Berat Rata-Rata Udang/ Average Body Weight (ABW), dan Laju Pertumbuhan harian udang/ Average Daily Growth (ADG). Aspek ekonomi dianalisis kelayakan finansial menggunakan Laba/Rugi, Benefit Cost Ratio (B/C ratio), Break Even Point (BEP), Paback Periode (PP). Identifikasi masalah pada performansi kinerja budidaya dianalisis menggunakan Root Cost Analysis terkait dalam pegelolaan sumberdaya manusia, metode pelaksanaan produksi, material yang digunakan serta saraa dan prasarana berupa mesin yang digunakan, kemudian data dianalisis menggunakan Fish Bone Diagram.

\section{Hasil dan Pembahasan}

\section{Kinerja Budidaya}

Performansi kinerja budidaya sebagai indikator atau tolak ukur dalam keberhasilan budidaya di PT. Suri Tani Pemuka yaitu mencakup ABW, ADG, produktivitas, SR dan FCR. Target produksi dinilai menggunakan SOP perusahaan sebagai penentu keberhasilannya. Keberhasilan produksi juga dapat dilihat dari perbandingan dengan siklus sebelumnya. Adapun target produksi dapat dilihat pada Tabel 2.

Tabel 2. Target Produksi

\begin{tabular}{|c|l|c|}
\hline No & \multicolumn{1}{|c|}{ Parameter } & Target \\
\hline 1 & ABW & $16,6 \mathrm{~g} / \mathrm{ekor}$ \\
\hline 2 & ADG & $0,25 \mathrm{~g} / \mathrm{ekor} / \mathrm{hari}$ \\
\hline 3 & Produktivitas & 12 ton/Ha \\
\hline 4 & SR & $85 \%$ \\
\hline 5 & FCR & 1,2 \\
\hline
\end{tabular}

\section{Produktivitas}

Produktivitas merupakan salah satu faktor penting penentu peningkatan hasil produksi kegiatan usaha budidaya. Produktivitas budidaya udang vaname di PT STP pada siklus 1 dan 2 tahun 2019 pada 9petakan yang diamati dapat dilihat pada Gambar 1. 
Buletin JSJ, 2 (1), 2020, 37-47

Available online di: http://ejournal-balitbang.kkp.go.id/index.php/JSJ/index

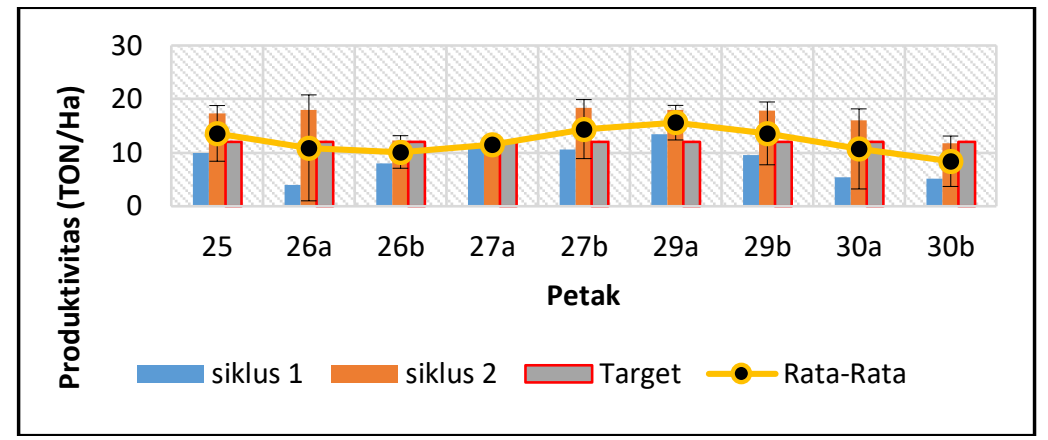

Gambar 1. Produktivitas udang vaname

Dari nilai Produktivitas 9 petakan pemeliharaan yang diamati pada siklus 1 yaitu berkisar antara 3,94-11,22 ton/Ha dan siklus 2 berkisar antara 11,91-17,92 ton/Ha. Produktivitas pada petak pemeliharaan yang diamati, dimana petakan yang belum memenuhi target yaitu pada petak 27a dan 30b. Rendahnya produktifitas pada petak 27 a disebabkan karena udang teserang penyakit IMNV sehingga dilakukannya panen dini sedangkan pada 30b nilai produktivitas rendah disebabkan oleh jumlah tebaran lebih tinggi. Padat tebar benur yang tinggi juga mempengaruhi hasil produktivitas. Hal ini sependapat dengan Hartoyo dkk(2018) bahwa penggunaan benur yang tidak sesuai dengan jumlah yang ditentukan terutama melebihi SOP mengakibatkan persaingan udang dalam mendapatkan tempat hidup, oksigen terlarut, dan pakan menyebabkan menurunnya kinerja budidaya.

\section{Survival Rate/SR}

Tingkat kelangsungan hidup atau SR udang vaname bervariasi pada setiap petakan tambak. Perolehan SR pada siklus 1 dan 2 dapat dilihat pada Gambar 2.

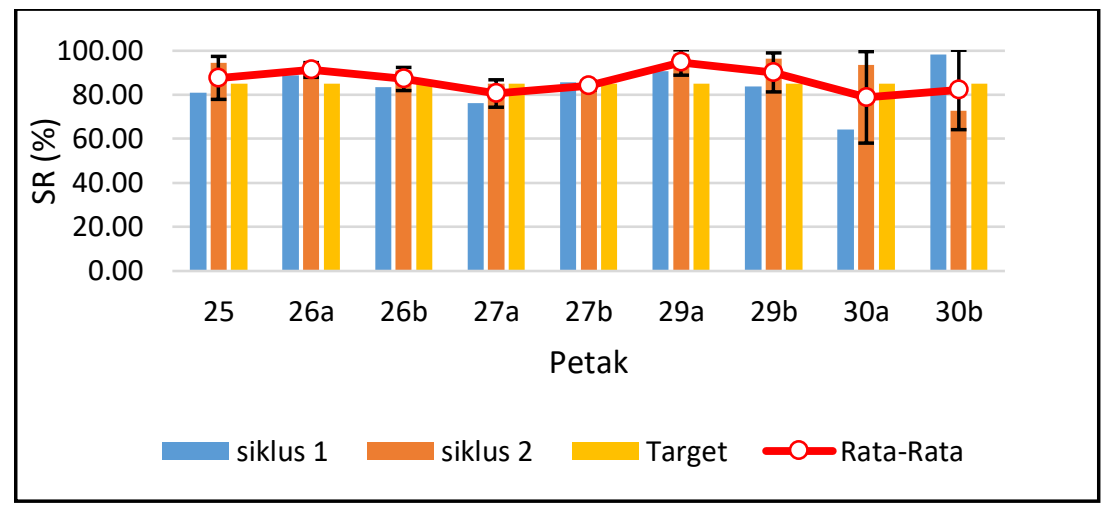

Gambar 2. Survival Rate (SR)

Kisaran SR pada siklus 1 berkisar 64,16 - 98,34\%, siklus 2 berkisar 72,85-98,77\%. Berdasarkan target perusahaan pada siklus satu terdapat 5 petak yang mempunyai nilai SR dibawah target.Tingkat kematian udang yang tinggi pada siklus 1 disebabkan akibat penyakit pada udang, sedangkan pada siklus dua petak terdapat 2 petak yang dibawah target. Terdapat beberapa penyebab rendahnya perolehan SR terkait dengan

mortalitas udang pada dasar tambak. Rendahnya

perolehan SR disebabkan serangan virus IMNV. Hal ini sesuai dengan pendapat Sukenda dkk., (2011) virus IMNV dapat menyebabkan mortalitas sekitar 60\%. Sehingga untuk meminimalisir biaya produksi dan terjadinya kontaminasi virus pada petakan disekitarnya maka dilakukan pemanenan dini pada usia 60-70 hari. 
Buletin JSJ, 2 (1), 2020, 37-47

Available online di: http://ejournal-balitbang.kkp.go.id/index.php/JSJ/index

\section{Food Convertion Rate (FCR)}

FCR merupakan salah satu indikator seberapa jauh pakan yang diberikan dapat dimanfaatkan oleh udang untuk mendukung pertumbuhan dan SR. Nilai FCR menggambarkan jumlah pakan yang diperlukan untuk menaikkan $1 \mathrm{~kg}$ berat udang. Semakin rendah nilai FCR, maka pakan digunakan semakin efisien. Berikut nilai FCR pada masing-masing petak pemeliharaan yan diamati pada siklus 1 dan 2 yang disajikan pada Gambar3.

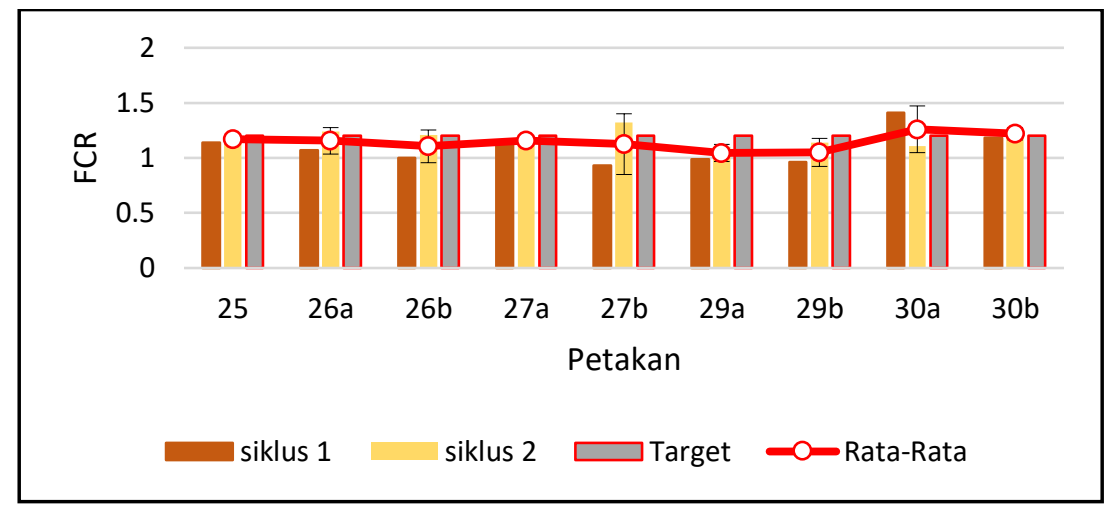

Gambar 3. Food Convertion Ratio

Adapun kisaran FCR pada siklus 1 yaitu 0,93-1,41 dan kisaran FCR pada siklus 2 yaitu 1,11,32. Dari persentasi perolehan FCR rata-rata pada siklus 1 terdapat 1 petak pemeliharaan nilai FCR tinggi dari target perusahaan yaitu pada petak 30a dengan FCR 1,41. Dan pada siklus 2 terdapat 4 petak pemeliharan yang memiliki FCR tinggi dari target produksi perusahaan. Adanya perbedaan nilai FCR tersebut dipengaruhi oleh kurang tepatnya perhitungan dalam pendugaan populasi udang, sehingga menyebabkan jumlah pemberian pakan tidak sesuai.

\section{Average Body Weight (ABW)}

Adapun berat rata-rata udang pada panen di PT STP Unit Sobo cenderung rendah atau tidak dapat mencapai target perusahaan. Target rata-rata berat udang yang ditetapkan oleh perusahaan yaitu 16,6 g/ekor. Adapun Perolehan ABW pada siklus 1 dan 2 dapat dilihat pada Gambar 4.

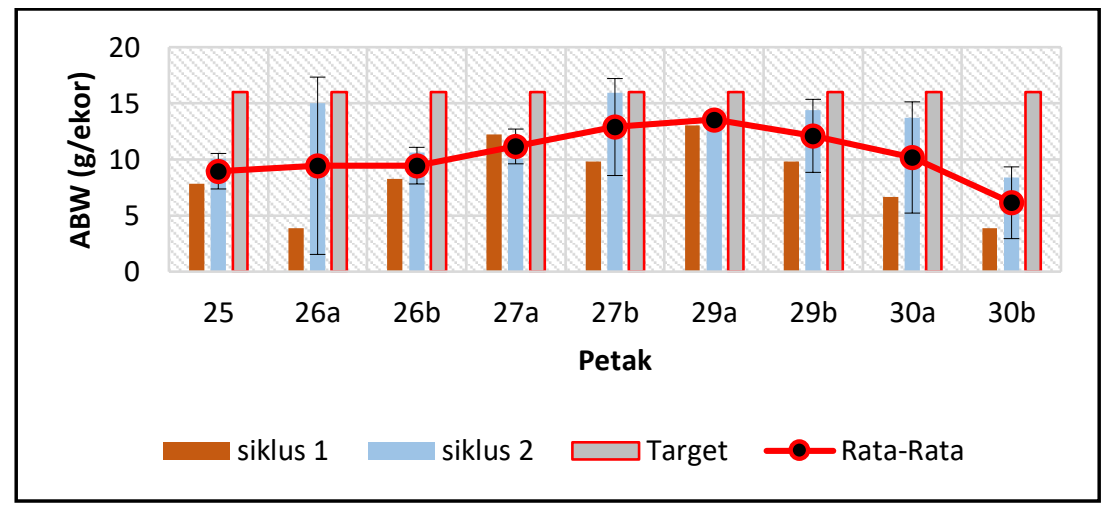

Gambar 4. Average Body Weight 
Berdasarkan Gambar perolehan ABW persiklus bervariasi pada setiap petakan. Adapun berat rata-rata udang pada siklus 1 berkisar antara 3,85 - 12,25 g/ekor sedangkan pada siklus 2 yaitu antara 8,4-15,94 g/ekor, dari hasil ABW panen persiklus diperoleh peningkatan dari siklus 1 ke siklus 2 namun, belum mencapai target perusahaan dimana target ABW panen perusahaan yaitu $16.6 \mathrm{~g} /$ ekor atau pada udang size 60 . Rendah nya peroleha $A B W$ tersebut karena pemanenan dini akibat serangan penyakit IMNV. Pemanenan dilakukan yaitu pada DOC < 75 dimana tidak sesuai target DOC pemanenan perusahaan yaitu minimal pada DOC 80. Serangan IMNV menyebabkan kerusakan jaringan tubuh udang pada histologi otot berupa necrosis dan kehilangan transparantasi (Umiliana dkk., 2016). Selain itu, padat tebar yang tinggi mempengaruhi rendahnya perolehan ABW. Sesuai dengan pendapat Pratama dkk.,(2017) pertumbuhan udang dipengaruhi oleh kepadatan udang. Kepadatan udang yang tinggi akan meningkatkan kompetisi, tempat hidup, makanan dan oksigen.

\section{Average Daily Growth (ADG)}

Perolehan nilai rata-rata pertumbuhan harian udang hasil panen pada petak pemeliharaan bervariasi. Adapun perolehan nilai ADG udang vaname pada siklus 1 dan 2 dapat dilihat pada Gambar 5.

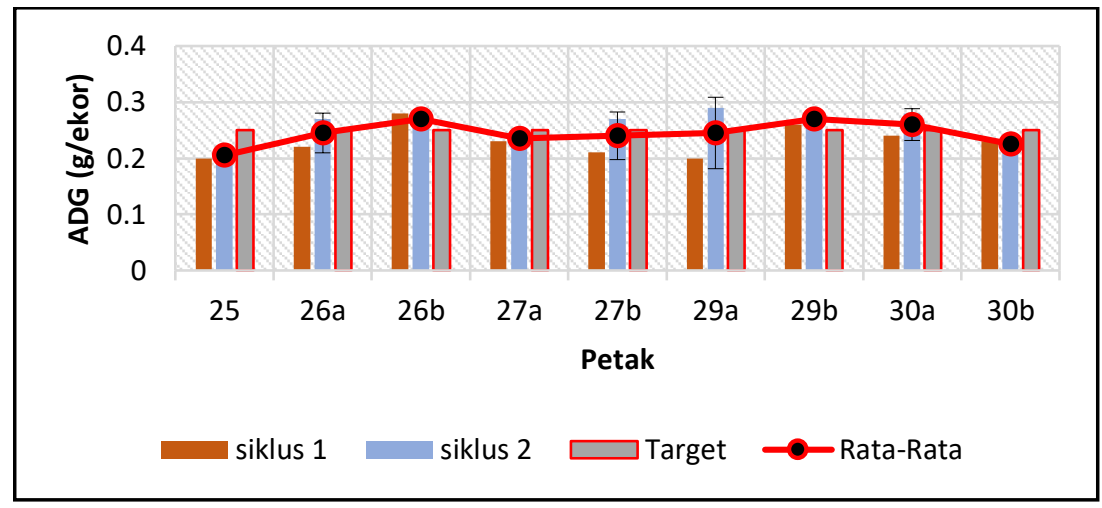

\section{Gambar 5 . Average Daily Growth}

Berdasarkan hasil Gambar Pertumbuhan rata-rata udang perhari diperoleh, adapun kisaran ADG pada siklus 1 berkisar antara 0,20 - 0,28 sedangkan pada siklus ke 2 nilai ADG berkisar antara 0,21 - 0,29 dimana dari hasil ADG yang diperoleh menunjukan peningkatan pertumbuhan rata-rata udang perhari dari siklus sebelumnya. Namun, pada target ada beberapa kolam yang belum mencapai target ADG. Hal tersebut dikarenakan kurang optimalnya kualitas air pada tambak mengakibatkan udang mengalami gangguan penurunan nafsu makan, dan mudah terserang penyakit. Kualitas air yang menurun tersebut memicu rendahnya perolehan ADG udang.

\section{Identifikasi Masalah}

Berdasarkan hasil performansi kinerja budidaya dari siklus 1 hingga siklus ke 2. Maka dilakukan identifikasi masalah menggunakan fishbone analysis. Penyabab utama terjadinya penurunan performansi budidaya diakibatkan oleh faktor manusia, pelaksanaan metode, bahan dan material, serta sarana dan prasarana. Fishbone analysis disajikan pada Gambar 6. Berdasarkan gambar tersebut dapat diketahui beberapa faktor yang menyebabkan udang terserang penyakit IMNV yang menyebabkan perolehan ABW yang rendah. Permasalahan yang terjadi dibatasi oleh empat aspek produksi meliputi: 
Buletin JSJ, 2 (1), 2020, 37-47

Available online di: http://ejournal-balitbang.kkp.go.id/index.php/JSJ/index

\section{Manajemen sumber daya manusia}

Dilihat dari segi pengelolaan sumber daya manusia, terdapat beberapa karyawan yang belum melaksanakan tugasnya dengan baik. Sebagai contoh, masih ada feeder yang lalai dalam melakukan penyiponan. Hal ini dikarenakan kurangnya rasa tanggung jawab terhadap beban tugas yang diberikan. Serta kurangnya kordinasi antara sesama petambak budidaya disekitar lokasi perusahaan dalam persoalan pembuangan limbah, yang berakibat ketika dalam pengambilanair, air yang dipasok sudah tercemar oleh limbah hasil buangan.

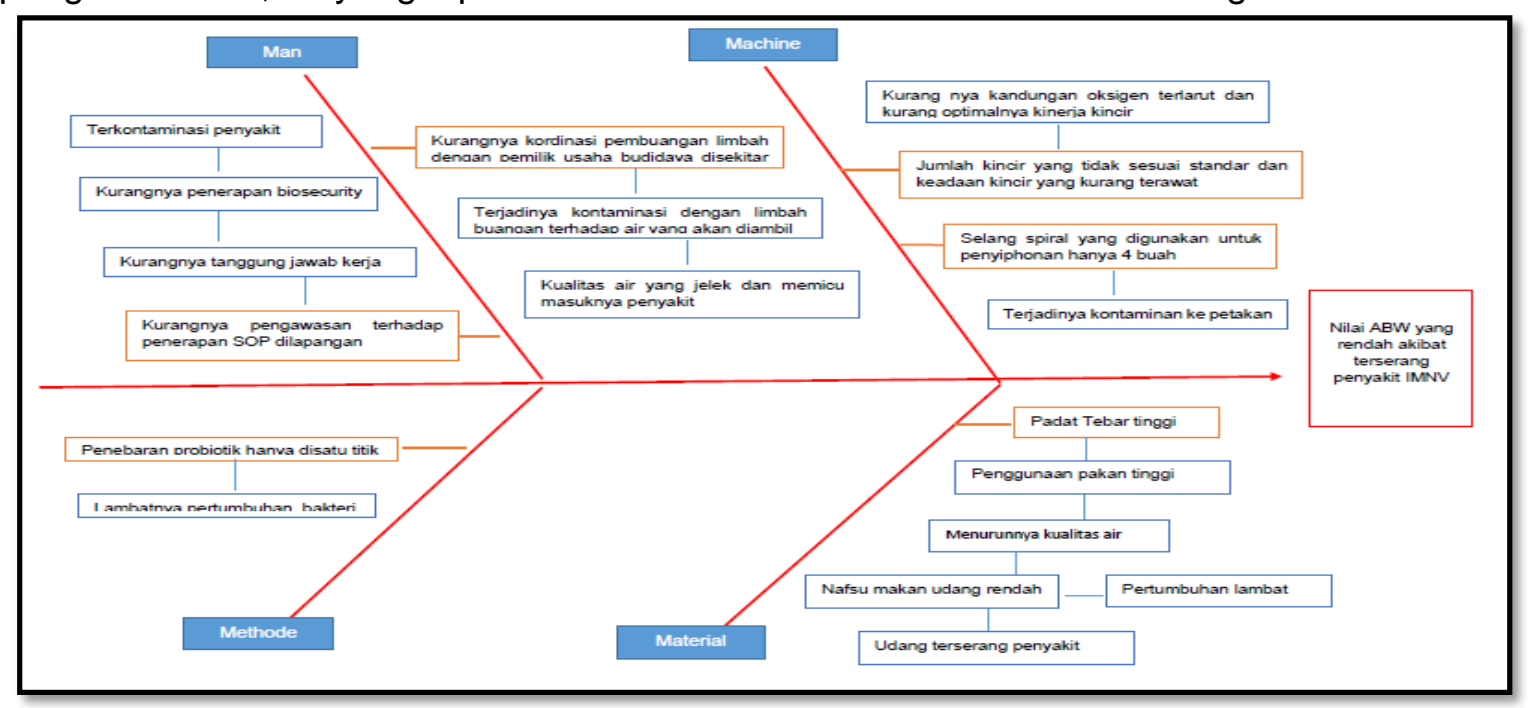

Gambar 6. Fishbone

\section{Metode yang dilakukan}

Penebaran probiotik yang hanya disatu titik, yang menyebabkan lambatnya proses pengadukan terhadap probiotik yang menyebabkan lambat nya pertumbuhan bakteri dimedia budidaya.

\section{Mesin yang digunakan}

Pada pelaksanaan produksi, Hanya mempunyai 2 selang spiral untuk melakukan penyiponan. Hal ini mengakibatkan kontaminan dari kolam. Penggunaan selang spiral yang digunakan pada saat penyiponan dari kolam satu ke kolam lainnya. Selain itu, penggunaan kincir yang usia pemakaiannya sudah lama dan tidak ada penambahan kincir serta tidak sesuainya kebutuhan kincir dalam petak produksi, dimana dapat mengakibatkan kualitas air yang buruk serta hasil produksi yang menurun.

\section{Metode}

Pada pelaksanaan produksi, dilakukan penebaran benur yang tidak sesuai dengan target, dimana pada saat pemesanan benur, benur yang datang lebih dari permintaan benur, maka perusahaan mengambil keputusan untuk memasukan benur kedalam beberapa petakan tambak, dimana jumlah benur yang ditebr tidak sesuai dengan target, hal tersebut menimbulkan kepadatan tinggi di petakan, dipetakan.

\section{Usulan Pemecahan Masalah}


Buletin JSJ, 2 (1), 2020, 37-47

Available online di: http://ejournal-balitbang.kkp.go.id/index.php/JSJ/index

Berdasarkan masalah yang terjadi terdapat beberapa usulan pemecahan masalah untuk mencegah penyakit IMNV menyerang sehingga dapat memperbaiki performansi kinerja budidaya. Adapun usulan pemecahan masalah dapat dilihat pada Tabel 3. 
Buletin JSJ, 2 (1), 2020, 37-47

Available online di: http://ejournal-balitbang.kkp.go.id/index.php/JSJ/index

Tabel 3. Usulan pemecahan masalah

\begin{tabular}{|c|l|l|}
\hline NO & \multicolumn{1}{|c|}{ Indikator } & \multicolumn{1}{c|}{ Usulan pemecahan masalah } \\
\hline 1 & $\begin{array}{l}\text { Kurangnya pengawasan terhadap } \\
\text { penerapan SOP }\end{array}$ & $\begin{array}{l}\text { Perlu diadakan arahan dari pihak manajer } \\
\text { kepada karyawan mengenai pentingnya } \\
\text { penggunaan SOP dan kegiatan budidaya yang } \\
\text { dilakukan }\end{array}$ \\
\hline
\end{tabular}

\begin{tabular}{|c|l|l|}
\hline 2 & $\begin{array}{l}\text { Kurangnya kordinasi dengan pemilik } \\
\text { usaha budidaya disekitar lokasi } \\
\text { mengenai pembuangan limbah }\end{array}$ & $\begin{array}{l}\text { Melakukan kordinasi dengan pemilik usaha } \\
\text { budidaya disekitar lokasi perusahaan }\end{array}$ \\
\hline 3 & Pemberian probiotik hanya disatu titik & $\begin{array}{l}\text { Penebaran dilakukan secara mengeliling atau } \\
\text { dapat dilakukan dengan menebar probiotik } \\
\text { didekat area kincir }\end{array}$ \\
\hline 4 & $\begin{array}{l}\text { Rendahnya dosis pemberian bahan } \\
\text { sterilisasi }\end{array}$ & $\begin{array}{l}\text { Penambahan dosis bahan sterilisasi ataupun } \\
\text { penambahan treatment untuk membunuh } \\
\text { mikroorganisme }\end{array}$ \\
\hline 5 & $\begin{array}{l}\text { Hanya mempunyai 2 selang spiral untuk } \\
\text { melakukan penyiponan }\end{array}$ & $\begin{array}{l}\text { Menambahkan jumlah selang spiral guna } \\
\text { menghindari kontaminasi saat melakukan } \\
\text { penyiponan }\end{array}$ \\
\hline 6 & $\begin{array}{l}\text { Kincir yang usia pemakaiannya sudah } \\
\text { lama dan jumlah kincir yang tidak sesuai } \\
\text { oleh kebutuhan }\end{array}$ & $\begin{array}{l}\text { Melakukan perbaikan dan perawatan kincir. } \\
\text { Dilakukan penambahan kincir untuk } \\
\text { meningkatkan produksi }\end{array}$ \\
\hline Pertumbuhan Lambat & $\begin{array}{l}\text { Melakukan perhitungan benur sebelum tebar dan } \\
\text { menargetkan benur yang akan ditebar }\end{array}$ \\
\hline
\end{tabular}

\section{Kesimpulan}

Teknis produksi yang dilaksanakan belum optimal dilihat dari target produksi yang belum tercapai. Hasil Performansi Kinerja Budidaya pada siklus selama praktik dan petakan yang diamati cenderung lebih meningkat dibanding siklus sebelumnya. Adapun key performansi yang diamati dengan pencapaian terhadap target perusahaan masing-masing yaitu produkttivitas $82 \%$, SR 78\%, FCR 58\%, ABW 0\%, dan ADG $66 \%$ serta Kualitas air cenderung tidak sesuai dengan ketetapan SNI (2006) dengan hanya dua parameter yang sesuai dengan SNI.

Target produksi belum tercapai dikarenakan kurangnya kedisiplinan karyawan, SOP tidak dijalankan, Padat tebar tinggi, peralatan kincir yang kurang memadai, dosis bahan sterilisasi yang rendah, serta teknik dalam pemberian probiotik yang kurang tepat dan belum optimal yang mengakibatkan terserang penyakit pada udang. Adapun usulan masalah yang dapat dilakukan meliputi pengawasan terhadap karyawan, pemilihan dan perhitungan benur serta menetapkan padat tebar benur yang sesuai SOP, Pengadaan kincir dan perbaikan serta penambahan vitamin untuk menjaga daya tahan tubuh.

\section{Daftar Pustaka}


Buletin JSJ, 2 (1), 2020, 37-47

Available online di: http://ejournal-balitbang.kkp.go.id/index.php/JSJ/index

Aedi, Nur. 2010. Pengolahan dan analisis data hasil penelitian. Fakultas IImu Pendidikan. Universitas Pendidikan Indonesia, Bandung.

Alamsyah, Firman. 2015. Analisis Akar Penyebab Masalah dalam Meningkatkan Overall Equipment Effectiveness (OEE) Mesin Stripping Hipack III dan Unimach di PT. PFI. Jurnal OE Vol. 7 No. 3. Hal. 289-302.

Mansyur, Abdul, Magampa. M, dan Suryanto S. H. 2014. Strategi pengelolaan pakan pada budidaya udang vaname (Litopenaeus vaname). Balai Penelitian dan Pengembangan Budidaya Air Payau.

Mustafa, Akhmad. 2008. Desain, Tata Letak dan Konstruksi Tambak. Jurnal Media Akuakultur. Vol. 3 No.2. Hal. 166-174.

Nur, Abidin. 2011. Manajemen pemeliharaan vaname. Direktorat Jendral Perikanan Budidaya.

Ridlo, Ali dan Subagiyo. 2013. Pertumbuhan, Rasio Konversi Pakan dan Kelulushidupan Udang Litopenaeus vannamei yang Diberi Pakan dengan Suplementasi Prebiotik FOS (Fruktooligosakarida). Buletin OseanografiMarina Oktober 2013 Vol. 12 No. 4. Hal. 18.

Rismahardi, Gea. G. 2012. Aplikasi Fishbone Analysis dalam Meningkatkan Kualitas Pare Putih di Aspakusa Makmur Kabupaten Boyolali. e-JurnalAgrista Universitas Sebelas Maret. Surakarta.

Saefulhak, Asep. 2004. Metode pendugaan biomassa dan produktivitas udang vaname pada tambak biocrete. Skripsi. Institute Pertanian Bogor.

Sagita, andi, Hutabarat Johannes, dan Sri Rejeki. 2015. Strategi Pengembangan Budidaya tambak Udang Vanname (Litopenaeus vannamei) di Kabupaten Kendal, Jawa Tengah. Journal of Aquaculture Management and Technology Volume 4, Nomor 3, Halaman 1-11

Sawhney. 2010. Growth Response and feed conversion efficiency of tor putitora (Ham.) Fry at Varying dietary protein levels. Department of zoology, University of jammu, India. 